\title{
Okul Yönetici ve Öğretmenlerinin Değişime Hazır Bulunuşluk Durumlarının İncelenmesi (Gaziantep İli Örneği) ${ }^{1}$
}

\author{
DOI: 10.26466/opus.874249 \\ * \\ Aykar Tekin Bozkurt * \\ * Dr. Öğr .Üyesi, Gaziantep Üniversitesi, Eğitim Fakültesi, Gaziantep/Türkiye \\ E-Posta: aykarbozkurt@gantep.edu.tr \\ ORCID: $\quad \underline{0000-0002-1936-2808}$
}

\section{Öz}

Bu araştırma, Türkiye'deki okullarda yakın zamanda gerçekleştirilmeye başlanan "FATIH Projesi (Fırsatları Artırma ve Teknolojiyi İileştirme Hareketi)" değişim örneğine ilişkin okul çalışanlarının (okul yöneticisi ve öğretmenler) değişime hazır bulunuşluk durumlarını ortaya koymak amacıyla yapılmıştır. Değiş̧ime hazır bulunuşluk; değişimlerin başarıyla gerçekleştirilmesi için kurumların kapasitesine ilişkin kurum üyelerinin inanç, tutum ve niyetlerini yansıtan önemli bir kavramdır. Veriler, 2014-2015 eğitim-öğretim dönemi süresince Gaziantep ili merkez ilçelerindeki devlet okullarının ortaöğretim kademesinde görev yapan okul çalışanlarının (n=14) katılımı ile elde edilmiştir. Araştırmada, çalışma grubu amaçl örnekleme yöntemiyle belirlenmiştir. Veriler, nitel araştırma tekniklerinden görüşme tekniği ile toplanmıştır ve analizinde içerik analizi kullanılmıştır. Araştırma bulgularına göre, okul çalı̧̧anlarının değişime hazır bulunuşluğun önemine ilişkin olumlu yantlar verdikleri, önem konusunun nedenine ilişkin; çalışana yönelik (özgüveni, iletişimi arttırmak, vb.) ve sürece yönelik (verimlilik, kontrol, vb.) nedenler belirttikleri belirlenmiştir. Ayrıca, FATiH Projesi bakımından, katılımoıların hazır bulunuşluk durumunu sağlamak için hizmet içi eğitimler, kurslar, seminerler, gibi eğitimler aldıklarl, bu süreçte meslektaşlar arası görüş alışverişinin sıklıkla kullanıldığı belirlenmiş̧tir.

Anahtar Kelimeler: Değişim, okullarda değişim, değişime hazır bulunuşluk, FATïH Projesi

\footnotetext{
${ }^{1}$ Bu makale yazarın hazırladığı doktora tezine dayalı olarak geliştirilmiştir
} 


\title{
An Investigation of School Administrators and Teachers' Readiness for Changes (A Case Study in Gaziantep)
}

\begin{abstract}
This study was conducted to reveal the readiness level of school staff (manager and teachers) related to change regarding the nation-wide "FATIH Project (Movement of Enhancing Opportunities and Improving Technology)" that recently started to be carried out in schools in Turkey. Readiness for change is an important concept that reflects the beliefs, attitudes and intentions of the institutional members regarding the capacity of institutions to ensure successful changes in the institution. Data were obtained during 2014-2015 academic year from the teachers and administrators $(n=14)$ working in secondary education schools in the central districts in Gaziantep province. In the study, the study group was determined by purposive sampling method. Of qualitative research techniques, the interview technique was used to collect data that analyzed by content analysis method. According to the research findings, it was determined that the school staff gave positive responses on the importance of being ready for change, and that they specified employee-oriented (self-confidence, improving communication, etc.) and process-oriented (efficiency, control, etc.) reasons. Moreover, in terms of the FATIH Project, it has been determined that participants received trainings such as in-service trainings, courses, seminars, etc. in order to ensure readiness and exchange of opinion among colleagues was frequently used in this process.
\end{abstract}

Keywords: Change, change in schools, readiness for change, FATIH Project 


\section{Giriş}

Günümüzde değişim ve yenilik kavramları sıklıkla kullanılmaktadır. İnsanlar ve örgütler değişimlerle karşı karşıya kalmakta ve uyum sağlamaya çalışmaktadır. Bu süreç insanlar ve örgütler üzerinde yoğun baskılar meydana getirebilmektedir (Çağlar, 2015, s.5). Bilişim ve teknoloji alanında yaşanan hızlı gelişimler ve bu gelişimlerle birlikte ortaya çıkan artan bilgi yoğunluğu tüm örgütsel yapıları yakından etkilemektedir ve bu etki örgütleri değişim ve dönüşüme yönlendirmektedir (Erdoğan, 2012, s.1). Değişim günümüzde kaçınılmaz bir hal almıştır. Gürses (2010, s.7) "niteliği nasıl olursa olsun; değişim olgusu vazgeçilemeyecek bir husus haline gelmiştir. Doğadaki her oluşum, ister istemez bu olguyla karşılaşmaktadır" şeklinde görüş bildirmiştir. İçinde yaşadığımız toplumda değişimlerin kaçınılmaz bir olgu haline gelmesi, bireylerin ve örgütlerin çevrelerinde meydana gelen değişmeleri anlamaları ve ayak uydurmaları varlıklarını devam ettirebilmeleri için önemli bir gereklilik olmuştur (Demirtaş, 2012).

Değişim konusu alan yazına baktığımızda belirli aşamaları içeren kapsamlı bir süreç olarak kabul edilmektedir (Erdoğan, 2012, s.17). Değişim süreci ile ilgili önemli çalışmaları olan Lewin (1947) değişim ile ilgili geliştirdiği modelinde değişim sürecini; çözülme aşaması, harekete geçme aşaması ve donma aşaması olarak anlatmaktadır. Bu modelde, Özdemir (2013, s.7)'e göre değişimin çözülmesi, örgütlerin değişime hazırlık yapması olarak, harekete geçiş örgütte değişim için çalışan üyelerin düşüncelerinin, duygu ve davranışlarının değişmesi; donma adımı ise örgütte değişimin kalıcılığının oluşması amacıyla yeni davranış biçimlerinin desteklenmesi olarak nitelendirilmektedir. Çözülme aşaması, organizasyon içinde açık ve net bir iletişime sahip olmak suretiyle istenen değişimlere hazırlanmayı hedeflemektedir (Camba ve Krotov, 2015). Ayrıca, Kotter (1996)'ın sekiz aşamada anlattığı değişim süreci modeli; sürecin ilk adımlarında değişime hazırlık eylemlerine yer vererek; 1.Bir aciliyet duygusu yaratmak, 2.Süreci yönlendirici güçlü bir ekibi (koalisyonu) bir araya getirmek, 3.Uygun bir vizyon oluşturmak ve 4.Değişim vizyonunu iletmek; şeklinde değişim çabalarını başarıya ulaştırmak için planlı ve koordineli bir hazırlık sürecinin varlığına vurgu yapmıştır. Fullan (2007) eğitimsel değişimleri incelediği çalışmasında, değişimi ilk 
olarak 'ihtiyaçlar-needs' ile başlatarak ihtiyacı tanımlayıcı çalışmaların yapılmasının önemine vurgu yapmıştır. Daha sonraki adımlarda, uygulama ve kurumlaştırma üzerinde durmuştur.

Hazır bulunuşluk (oluş) kavramı, eğitim bilimlerinde, özellikle eğitim psikolojisinde kullanılan önemli kavramlardan birisidir. İnsanın istenilen davranışı kazanabilmesi için gerekli donanıma sahip olması (Kaya, 2014, s.117), olarak tanımlanan hazır oluş, insanın yaşamında yer alan pek çok boyutta (biyolojik, duygusal, sosyal, vb.) ele alınabilmektedir. Değişim süreçleri açısından konuyu ele aldığımızda, değişime hazır bulunuşluk (oluş) durumu, değişimin kabulü veya reddi ile ilişkilendirilen davranışların habercisi olarak kavramsallaştırılmaktadır (Armenakis, Harris ve Mossholder, 1993). Bu hususta Kondakçı, Zayim ve Çalışkan (2010), örgütlerdeki değişim süreçlerinde örgütü hazır hale getirmenin sürecin temelini oluşturduğunu vurgulayarak, örgüt çalışanlarının değişime karşı tutumlarının anlaşılması ve değişim esnasında olumsuz yönlü kaygı, stres, huzursuzluk, vb. tutumların olumluya doğru değiştirmenin ihmal edilmemesi gerektiğine dikkat çekmişlerdir. Aksi halde örgüt çalışanlarının desteğini kazanamayan değişim girişimlerinin başarısızlıkla sonuçlanabileceği uyarısında bulunmuşlardır. Ayrıca, Willower (1963, s.259) çalışmasında, değişimin ilk aşamasında ortaya çıkabilecek dirençlerin, sürecin devamında da (uygulamada) sürebilme ihtimalinin olduğuna dikkat çekerek, bu yüzden örgütlerde değişimin ilk hazırlık aşamasında örgüt üyelerine yönelik uygun çalışmalar yapılarak hazır oluşlarının sağlanmasının önemini belirtmiştir.

Örgütsel değişim sürecine ilişkin olarak Armenakis ve diğerleri (1993) çalışmalarında örgütsel değişimlerin uygulanma sürecindeki verimliliğine pek çok faktörün katkıda bulunduğunu ve bu faktörlerden birinin değişime hazır bulunuşluk olduğunu belirtmişlerdir. Değişime hazır bulunuşluğu, örgüt üyelerinin değişim girişimine yönelik olarak direnç gösterme veya destek olma davranışlarının bilişsel bir göstergesi olarak tanımlayarak, kavramın temelinde örgüt çalışanlarında değişimin başarıyla gerçekleşebileceğine yönelik tutum, inanç ve niyetlerin yer aldığını vurgulamışlardır. Woodall (1996)'da değişim ilk aşaması olarak nitelenen çözülme aşamasına benzer anlatımlarda bulunarak, bu süreçte gerçekleştirilmesi planlanan değişimde doğru ve yanlış davranışların neler olduğu, değişime duyulan ihtiyacı belirleyecek kişilerin kimler 
olduğu, bununla birlikte yenilenmesi istenen örgütsel sistemin, yapı ya da işleyişin ihtiyaca neden cevap veremediği bilgisinin kim tarafından açıklanacağına ilişkin iki kritik sorunun değişimin benimsenmesi için önemine dikkat çekmiştir.

Eğitim alanındaki değişim sürecinde "okul" değişimin odağında yer almaktadır (Akan, 2007, s.2). Bu çalışmanın amacı, temel eğitim örgütleri olan okulların değişime hazır bulunuşluk durumunu bir değişim örneği olarak FATİH Projesi kapsamında incelemektir. Eğitimde FATíH Projesi (Fırsatları Arttırma ve Teknolojiyi İyileştirme Hareketi Projesi) eğitim ve öğretimde fırsat eşitliğini sağlamak ve okullarımızdaki teknolojiyi iyileştirmek amacıyla Bilişim Teknolojileri araçlarının öğrenme-öğretme sürecinde daha fazla duyu organına hitap edilecek şekilde, derslerde etkin kullanımı için; okulöncesi, ilköğretim ile ortaöğretim düzeyindeki tüm okullarımızın 570.000 dersliğine LCD Panel Etkileşimli tahta ve internet ağ altyapısının sağlanması planlayan (fatihprojesi.meb.gov.tr) bir değişim projesidir. $\mathrm{Bu}$ çalışma, örneklemde belirtilen okullar dahilinde, bu okullarda görev yapan okul çalışanlarının katılımı ile yürütülmüştür ve "değişime hazır bulunuşluk" konusu ülkemiz okullarında uygulanmaya başlanan en yeni ve en güncel değişim girişimlerinden birisi olarak "FATIHH Projesi" ne yönelik ele alınmıştır. Bu amaçla 'bu değişim sürecinde okul çalışanlarının hazır bulunuşluk durumları nasıldır ve bu duruma etki eden temel faktörler nelerdir?' ana problemi çerçevesinde incelemeye alınmıştır. Bu bağlamda konuyu daha detaylı incelemek adına, "okul çalışanları" kapsamında okullarda eğitim-öğretim süreci boyunca değişim süreçlerinde etkin görev alan okul yöneticileri ve öğretmenlere dönük olarak aşağıdaki alt sorulara cevaplar aranmaya çalışılmıştır:

1. Okul çalışanlarının başarılı değişimlerin gerçekleştirilmesi için önemli gördükleri başlıca faktörler/unsurlar nelerdir?

2. Okul çalışanlarının bir değişim başlatılırken; değişime hazır bulunuşluk durumunu sağlamanın önemine yönelik görüşleri nasıldır?

3. Okul çalışanlarının okullarda yeni bir değişim örneği olan "FATİH Projesi" ne yönelik hazır bulunuşluk durumlarına ilişkin görüşleri nasildir? 


\section{Yöntem}

\section{Araştırmanın Deseni}

Araştırma, nitel bir araştırmadır. Nitel araştırmalarda katılımcıların bakış açılarının ortaya çıkarılması önemlidir ve nitel araştırmalarda öncelikli amaç katılımcı bakış açısını yansıtabilmektir (Saban ve Ersoy, 2017, s.8). Bu araştırma durum çalışmasına göre desenlenmiştir. Durum çalışmasında, bir duruma ilişkin etkenler (ortam, bireyler, olaylar, süreçler, vb.) bütüncül bir yaklaşımla araştırılır ve ilgili durumu nasıl etkiledikleri ve ilgili durumdan nasıl etkilendikleri üzerine odaklanılır (Yıldırım ve Şimşek, 2005, s.77).

\section{Çalışma Grubu}

Bu çalışmanın çalışma grubunu Gaziantep ili merkez ilçelerinde (Şahinbey ve Şehitkamil ilçeleri) bulunan, MEB'e bağlı devlet ortaöğretim okullarında 2014-2015 eğitim-öğretim yılında görev yapmakta olan okul çalışanları (4 okul yöneticisi ve 10 öğretmen, toplam 14 katılımc1) oluşturmaktadır. Çalışma grubunun seçiminde izlenen yol ise şu şekildedir; amaçlı örnekleme yöntemlerinden yola çıkılarak, eğitimde bir değişim örneği olarak FATİH Projesinin uygulamaya başladığ1 ortaöğretim okulları arasından; FATİH Projesinin başlatılma süresi 0-1. yıl; 1-2. yıl ve 2.yıl ve üzeri süre geçen okullar belirlenmiştir. $\mathrm{Bu}$ okullar arasından maksimum çeşitlilik örneklemesi ile maksimum çeşitliliği sağlamak amaçlı olarak, her süreyi yansıtması bakımından projenin uygulanma süresine dair birer okul seçilerek (toplam üç okul) çalışma yürütülmüştür. Maksimum çeşitlilik örneklemesi ile çeşitlilik gösteren durumlar arasında herhangi ortak ya da paylaşılan olguların olup olmadığı bulunmaya çalışılır ve bu çeşitliliğe göre problemin farklı boyutlarını ortaya koymak amaçlanır (Yıldırım ve Şimşek, 2005, s.109).

Aşağıda Tablo 1'de çalışma grubunda yer alan katılımcı okul çalışanlarının demografik bilgileri yer almaktadır. 
Tablo 1. Çalışma Grubuna İlişkin Demografik Bilgiler

\begin{tabular}{llllll}
\hline $\begin{array}{l}\text { Katılımc1 } \\
\text { No }\end{array}$ & Cinsiyet & Yaş & $\begin{array}{l}\text { Kıdem } \\
(\mathbf{y} \mathbf{l})\end{array}$ & Branş & $\begin{array}{l}\text { FATíH } \\
\text { Pro.Uyg. Süresi }\end{array}$ \\
\hline Ö1 & Bayan & 34 & 12 & Matematik Öğretmeni & 2 \\
Ö2 & Bayan & 39 & 14 & Müzik Öğretmeni & 2 \\
Ö3 & Bayan & 51 & 26 & Biyoloji Öğretmeni & 2 \\
Ö4 & Erkek & 37 & 10 & Öğretmen & 2 \\
Ö5 & Erkek & 54 & 25 & Tarih Öğretmeni & 1 \\
Ö6 & Bayan & 43 & 19 & Müzik Öğretmeni & 3 \\
Ö7 & Erkek & 33 & 9 & Bilişim Tekn. Öğrt. & 3 \\
Ö8 & Bayan & 25 & 3 & Sağlik Meslek D. Öğrt. & 2 \\
Ö9 & Bayan & 28 & 3 & Matematik Öğretmeni & 3 \\
Ö10 & Bayan & 38 & 13 & Sağlik Meslek D. Öğrt. & 1 \\
Y1 & Erkek & 54 & 34 & Okul Müdürü & 2 \\
Y2 & Erkek & 39 & 16 & Okul Müdür Yard. & 1 \\
Y3 & Erkek & 48 & 20 & Okul Müdür Yard. & 2 \\
Y4 & Erkek & 39 & 15 & Okul Müdür Yard. & 3 \\
\hline
\end{tabular}

Tablo 1'den görüldüğü gibi, çalışma grubunda toplam 14 katılımc1 yer almaktadır. Katılımcılar, her okulda (toplam üç okul içinde) basit seçkisiz örnekleme yöntemi kullanılarak rastgele belirlenerek çalışma gerçekleştirilmiştir. Ayrıca, araştırmanın çalışma grubunda yer alan okul yöneticileri de yine çalışmanın yürütüldüğü okullarda görev yapma ve gönüllülük esasına dayalı bir şekilde belirlenmiştir. Tablo 1'e göre çalışma grubu cinsiyet açısından bakıldığında kadın ve erkek oranının yarı yarıya olduğu görülmektedir. Yaş, kıdem ve branş açısından da çeşitlilik sağlandığı söylenebilir.

Araştırmada katılımcıların araştırmaya katılımları sürecinde, nitel araştırmalardaki etik yönde dikkate alınarak katılımcıların kimliklerinin gizli kalacağ 1 ve toplanacak verilerin sadece bilimsel araştırma süreci için kullanılacağı bildirilmiştir. Nespor (2000) da çalışmalardaki etik yöne dikkat çekmiş ve katılımcılara araştırmanın amacının, verilerin nerde kullanılacağı, gibi bildirimlerin yapılmasının önemini belirtmiştir.

\section{Verilerin Toplanması ve Analizi}

Veriler nitel araştırma yöntemlerinden görüşme tekniği ile toplanmıştır. Görüşme, sosyal bilimlerde en sık kullanılan araştırma yöntemlerinden birisidir (Yıldırım ve Şimşek, 2005, s.119). Araştırmacı tarafından 
kavramsal çerçeveye bağlı kalınarak öğretmenler ve okul yöneticileri için ayrı ayrı hazırlanan yarı-yapılandırılmış görüşme formları aracılığıyla nitel veriler toplanmıştır.

Görüşme formunda yer alan sorular: "Yeni fikirlere ve değişimlere istekli misinizdir? Okullarda başarılı değişimlerin gerçekleştirilmesini sağlayan temel etkenler/faktörler sizce nelerdir? Bir değişim başlatılırken; okul çalışanlarının hazır oluşu sizce önemli midir? Neden? FATİH Projesi değişimi okulunuzda başlatılırken, değişime hazır (hazırlıklı) olmanız için ne gibi faaliyetlerin/ etkinliklerin içinde yer aldınız? Bu faaliyetlerden bir ya da iki tanesini kısaca açıklar mısınız? Bu değişim sürecinde (geçiş sürecinde); hazır olma ve uyum sağlamada: Size zor gelen şeyler oldu mu? (Olduysa ne gibi zorlaştıran etkenler oldu?) Size kolaylık sağlayan şeyler oldu mu? (Olduysa ne gibi kolaylaştıran etkenler oldu)? Bu sürece yönelik önerileriniz (eğer varsa) nedir?" şekilde sıralanmaktadır. Görüşmeler, araştırmacı tarafından katılımclarla yaklaşık 30-35 dakika süre içerisinde ve yüz yüze gerçekleştirilmiştir. Görüşmeciden izin alınarak kayıt cihazı kullanılmış ve ayrıca cevapların aslına sadık kalarak not alma yöntemi ile veriler kaydedilmiştir.

Toplanan verilerin analizinde 'içerik analizi yöntemi' kullanılmıştır. İçerik analizi sürecinde, frekans analizi ve kategorisel analiz tercih edilmiştir. Bilgin (2006, s.18-19)'e göre frekans analizi yapılarak birim ve öğelerin sayısal, yüzdesel ve oransal bir tarzda görünme sıklığı ortaya konulur ve bu sayede, belirli bir öğenin yoğunluğu ve önemini anlamamıza katkıda bulunulur. Bu analiz sonunda, öğeler önem sırasına sokulur ve yapılan analize bağlı sıklık duruma dayalı bir sınıflama ortaya konur. Nitel araştırmalarda tematik çözümleme (kodlama) işlemi aşamasında veriler incelendikten sonra belirli kategoriler altında (kategorisel analiz) toplayabilmek için temalar oluşturulur. Temalar oluşturulurken ortak özellik içeren kodlar bir araya getirilmeye çalışılır. Ortak ya da farklı özellik gösteren kodlar bir araya getirilerek temalar ortaya konur (Karataş, 2015). Araştırmanın nitel veri analizi; verilerin yazıya dökülmesi, görüşme kodlama anahtarının oluşturulması, görüşme verilerinin kodlama anahtarına kodlanması, kodlamaların karşılaştırılması ve güvenirlik çalışması, elde edilen bulguların yorumlanması adımları (Miles ve Huberman, 1994; Yıldırım ve Şimşek, 
2005, Bilgin, 2006, Saldana, 2009) izlenerek gerçekleşmiştir. Toplanan verilerin geçerlik/güvenirliğini arttırmak için Miles ve Huberman (1994)'ın geliştirdiği "Uzlaşma Yüzdesi" hesaplanmıştır. Uzlaşma yüzdesi $(\mathrm{P})=$ Görüss Birliği $(\mathrm{Na}) /($ Görüş birliği $(\mathrm{Na})+$ Görüş Ayrılığ 1 $(\mathrm{Nd}))$ x 100 formülü ile hesaplanmış ve $\mathrm{P}=(80 / 80+10) \times 100=\% 88,8$ $\sim 90$ 'a yakın bir değer olarak saptanmıştır. Hesaplanan bu değerin \%70'in üzeri olarak ortaya çıkması- nitel araştırmaların güvenirliliği için hesaplanan uzlaşma yüzdesinin \%70'in üzerinde olması yönündedir (Miles ve Huberman, 1994)- araştırmanın güvenirliğinin yeterli düzeyde olduğunu ve temalar üzerinde görüş birliğine varıldığının göstergesidir. Ayrıca, görüşmeye katılan katılımcıların görüşlerinden doğrudan alıntılar da yapılarak çalışmada yer verilmiştir. Görüşmenin niteliğini arttırıcı ortama sadık kalınması ve görüşmelerin nasıl gerçekleştirildiği açıklanarak araştırmanın dış güvenirliliği arttırılmıştır. Araştırmadan elde edilen verilerin sonuçları ve yorumları katılımcılara (okul yöneticilerine ve öğretmenlere) teyit ettirilerek ve uzman incelemesine başvurularak iç geçerlik düzeyi arttırılmıştır.

\section{Bulgular ve Yorum}

\section{Birinci Alt Probleme İlişkin Bulgular}

“Okul çalışanlarının (okul yöneticisi ve öğretmen) başarılı değişimlerin gerçekleştirilmesi için önemli gördükleri başlıca faktörler/unsurlar nelerdir?" alt problemine ilişkin, katılımcıların ortak ifadelerinden yola çıkılarak, okullarda başarılı değişimlerin gerçekleştirilmesini sağlayan ana faktörler; çalışanlara, kuruma ve gerçekleştirilmesi planlanan değişimin özelliğine ilişkin olarak temalandırılmıştır. Alınan yanıtlar doğrultusunda oluşturulan alt tema ve kodlar Tablo 2'de verilmiştir.

Tablo 2'ye göre okul çalışanlarına göre değişimlerde başarı faktörleri alt temasında; değişimlerin başlatılmasına başarıyı sağlayıcı faktörlere yönelik katılımcıların çoğunluğunun çalışanlara yönelik; çalışanlar arasındaki ilişki ve iş birliğini ön plana çıaran faktörleri belirttiği görülmüştür. Bu konudaki örnek ifadeler; "Bence uyumlu ekip çalışması önemlidir" (Y:2), "Öğretmen-öğrenci ilişkisini güçlendirici, öğrenciyi derse aktif katan, kendine değer verildiğini hissettiren çalışmalarla başarının 
artacağını düşünüyorum" (Ö:8), "Kararlı idareciler ve işinin hakkını vermek isteyen öğretmenler başarılı değgişimleri să̆layacaktır." (Ö:9), şeklindedir.

Tablo 2. Katılımcıların Başarılı Değişimlerin Gerçekleştirilmesini Sağlayan Temel Faktörlere İlişkin Görüşlerinin Tematik Çözümlemesi

\begin{tabular}{|c|c|c|}
\hline Tema & Alt Temalar & İfadeler (Kavramsal Kodlar) \\
\hline \multirow{3}{*}{ 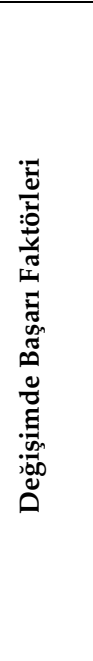 } & $\begin{array}{l}\text { 1. Çalışanlara Yönelik } \\
\text { Başarı Faktörleri }(n=13)\end{array}$ & $\begin{array}{l}\text { Personelin kararlılı̆̆ı } \\
\text { Öğretmen-öğrenci ilişkisi } \\
\text { Yönetici -öğretmen ilişkisi } \\
\text { Yöneticinin liderlik özellikleri } \\
\text { Çalışanların donanımlı oluşu (yetkinliği) } \\
\text { Koordineli/uyumlu çalışma ruhu } \\
\text { İstek ve motivasyon }\end{array}$ \\
\hline & $\begin{array}{l}\text { 2. Kuruma Yönelik } \\
\text { Başarı Faktörleri }(n=7)\end{array}$ & $\begin{array}{l}\text { Kurumun fiziki ortamının uygunluğu/hazır oluşu } \\
\text { Teknolojik imkanların hazır olması } \\
\text { Kapsamlı bilgi tabanının oluşturulması } \\
\text { Kurumun sosyal (eğitsel) yönden hazır oluşu } \\
\text { Tüm paydaşların desteği } \\
\text { Kurumun yeniliklere isteği/açıklığı }\end{array}$ \\
\hline & $\begin{array}{l}\text { 3. Değişimin Özelliğine } \\
\text { Yönelik Başarı Faktörleri } \\
(n=5)\end{array}$ & $\begin{array}{l}\text { İhtiyaca yönelik olması } \\
\text { Güncel olması } \\
\text { Kullanılabilir olması } \\
\text { Öğrenci/insan merkezli bakış açısı }\end{array}$ \\
\hline
\end{tabular}

Kuruma yönelik başarı faktörleri alt temasında; katılımcıların kurumun fiziki alt yapısının tamamlanması, teknolojik donanımın sağlanması, kurum geneli yeniliğe isteklilik, gibi faktörleri sıklıkla belirttiği belirlenmiştir. Bu konudaki örnek ifadeler; "İdare, öğretmen ve öğrencinin koordineli çalışması, ayrıca velilerin ve İlçe Milli Ĕ̆itim Müdürlüklerinin bu konuda okullara tam destek vermesi çok önemlidir" (Ö:1), "Fiziki anlamda sınfflarımızın Avrupa standartlarında geliştirilmesi gereklidir" (Y:4), "Değişimler başlatılırken okullarda kapsaml bir bilgi tabanı oluşturulmalıdır" (Ö:5), şeklinde tespit edilmiştir.

Değişimin özelliğine yönelik başarı faktörleri alt temasında ise katılımcıların başlatılacak değişimin özelliğine vurgu yapan ihtiyaca yönelik olma ve güncellik gibi faktörleri belirttiği belirlenmiştir. Bu konudaki örnek ifadeler; "Değişimlerin insan merkezli bir bakış açısıyla hazırlanması gereklidir" (Ö:3), "Değişimlerin ihtiyaca yönelik ve ayrıca kullanılabilir olması çok önemlidir" (Ö:7), şeklinde tespit edilmiştir. 


\section{İkinci Alt Probleme İlişkin Bulgular}

“Okul çalışanlarının (okul yöneticisi ve öğretmen) bir değişim başlatılırken; değişime hazır bulunuşluk durumunu sağlamanın önemine yönelik görüşleri nasıldır?" alt problemine ilişkin olarak katılımclara bu süreçte çalışanların tutumunun tespitini sağlamak için öncelikle "Bir değişim başlatılırken; okul çalışanlarının hazır (hazırlıklı) oluşu sizce önemli midir" sorusu yöneltilmiştir ve katılımcların tümünün 'Evet' yanıtını verdiği belirlenmiştir. Böylece, katılımcıların konunun önemine yönelik tutumunun olumlu ve bu konudaki farkındalığın yüksek olduğu tespit edilmiştir. Sonrasında sorulan "Neden" sorusuna dönük katılımclardan alınan yanıtlar doğrultusunda oluşturulan alt tema ve kodlar Tablo 3'te verilmiştir.

Tablo 3. Katılımcıların Değişime Hazır Bulunuşluk Sürecinin Önemine İlişkin Görüşlerinin Tematik Çözümlemesi

\begin{tabular}{|c|c|c|}
\hline Tema & Alt Tema & İfadeler (Kavramsal Kodlamalar) \\
\hline 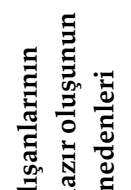 & $\begin{array}{l}\text { 1. Bireye-Çalışana } \\
\text { Yönelik } \\
\text { Nedenler }(n=8)\end{array}$ & $\begin{array}{l}\text { Değişime istekli ve inanan bireyler oluşturmak } \\
\text { Ekiplerin başarısını arttırmak } \\
\text { Kişinin bilgisi arttırmak } \\
\text { Kişinin özgüvenini arttırmak } \\
\text { Kişinin iletişim gücünü arttırmak }\end{array}$ \\
\hline 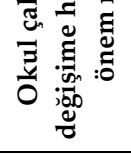 & $\begin{array}{l}\text { 2. Sürece Yönelik } \\
\text { Nedenler }(n=8)\end{array}$ & $\begin{array}{l}\text { Sürece uyumu kolaylaştırmak } \\
\text { Verimliliği arttırmak } \\
\text { Kontrol dışı durumları (aksaklıkları) önlemek } \\
\text { Öğrenci başarısını arttırmak }\end{array}$ \\
\hline
\end{tabular}

Tablo 3'ten görüldüğü gibi, değişime hazır bulunuşluk sürecinin önemine yönelik daha derin veriler elde etmek amacıyla katılımcılara sorulan 'neden' sorusuna alınan yanitlar iki alt tema altında; bireye ve sürece yönelik nedenler, incelenebilmektedir.

Tablo 3'ten katılımcıların bireye-çalışana yönelik nedenler alt temasında; çalışanın kendisine yönelik nedenleri sıklıkla belirttiği görülmektedir. Bu konudaki örnek ifadeler; "Öğretmenin hazırlıklı olması özgüveni açısından önemlidir. Özgüveni yüksek olan öğretmenler başarllı olur" (Ö:2), "Değişimin gerçekleşmeyeceğine inanan insanlarla değiş̧imi 
yaşatamazsınız. Öncelikle inanmak gerekir" (Ö:9), şeklinde tespit edilmiştir. Ayrıca, katılımcı öğretmenlerin bazıları değişimin bir ekip işi olduğu görüşü; "Değişim bir ekip işidir, bu sebeple ekipteki her bireyin hazır olması gerekir" (Ö:4), şeklinde tespit edilmiştir.

Tablo 3'ten katılımcıların sürece yönelik nedenler alt temasında; sürecin işleyişine yönelik nedenleri sıklıkla belirttikleri görülmektedir. "Değişim başlamadan önce 'neyi, niçin ve nasıl' değiştirmemiz gerektiğ konusunda hazırlanmamı karşılaşılacak aksaklikları engellemek adına önemlidir" (Y:2), şeklinde okul yöneticilerinin süreçteki işleyişte yaşanabilecek aksaklıkları önlemeye yönelik hazır oluşun önleyicilik rollerine vurgu yapan görüşleri tespit edilmiştir.

\section{Üçüncü Alt Probleme İlişkin Bulgular}

“Okul çalışanlarının (okul yöneticisi ve öğretmen) okullarda yeni bir değişim örneği olan 'FATİH Projesi'ne yönelik hazır bulunuşluk durumlarına ilişkin görüşleri nasıldır?" alt problemine ilişkin katılımclara yöneltilen sorulardan alınan yanıtlar doğrultusunda oluşturulan alt tema ve kodları gösteren Tablo 4'te verilmiştir.

Tablo 4'te görüldüğü gibi, katılımcılara öncelikle FATİH Projesine hazır olmak için ne gibi faaliyetlerin içinde yer aldıkları, daha sonra süreçte kolaylık ve zorluk yaşadıkları durumların neler olduğu ve önerileri sorulmuştur. Katılımcıların verdiği yanıtlar çerçevesinde oluşan temanın dört alt tema altında toplandığı görülmektedir.

Tablo 4'ten FATIHH Projesine hazır bulunuşluk etkinlikleri alt temasında; Katılımcıların çoğu projeye hazır oluş durumunu sağlamada 'hizmet içi eğitimlere' katıldıklarını belirtmiştir, ayrıca kurum değişikliğinden dolayı eğitime katılamayan bir öğretmen ve bir okul yönetici ise yeni dönem takviminde eğitimlerini alacaklarını belirtmiştir. Bunun yanı sıra, okullarda meslektaşlar arasında görüş alışverişinin sıklıkla yapıldığı; bilgisayar öğretmenlerinin de bu süreçte okul çalışanlarını bilgilendirme ve rehberlik yönünden önemli görevler yürüttüğü belirlenmiştir. Bu konudaki örnek ifadeler; “Teknoloji kullanım kursuna katıldık. Ayrıca bilgisayar öğretmenimiz okulda akıllı tahtayı ve EBA'yı nasıl kullanırız ile ilgili küçük gruplarla eğitimler verdi" (Ö:8), "Hizmet içi eğitimler var ama ben bu yıl başka bir kurumdan geldiğim için 
alamadım, bu Şubat-Mart döneminde alacağım" (Ö:10), şeklinde tespit edilmiştir.

Tablo 4. Katılımcıların FATİH Projesi Değişimi Sürecinde Hazır Bulunuşluk Durumuna İlişkin Görüşlerinin Tematik Çözümlemesi

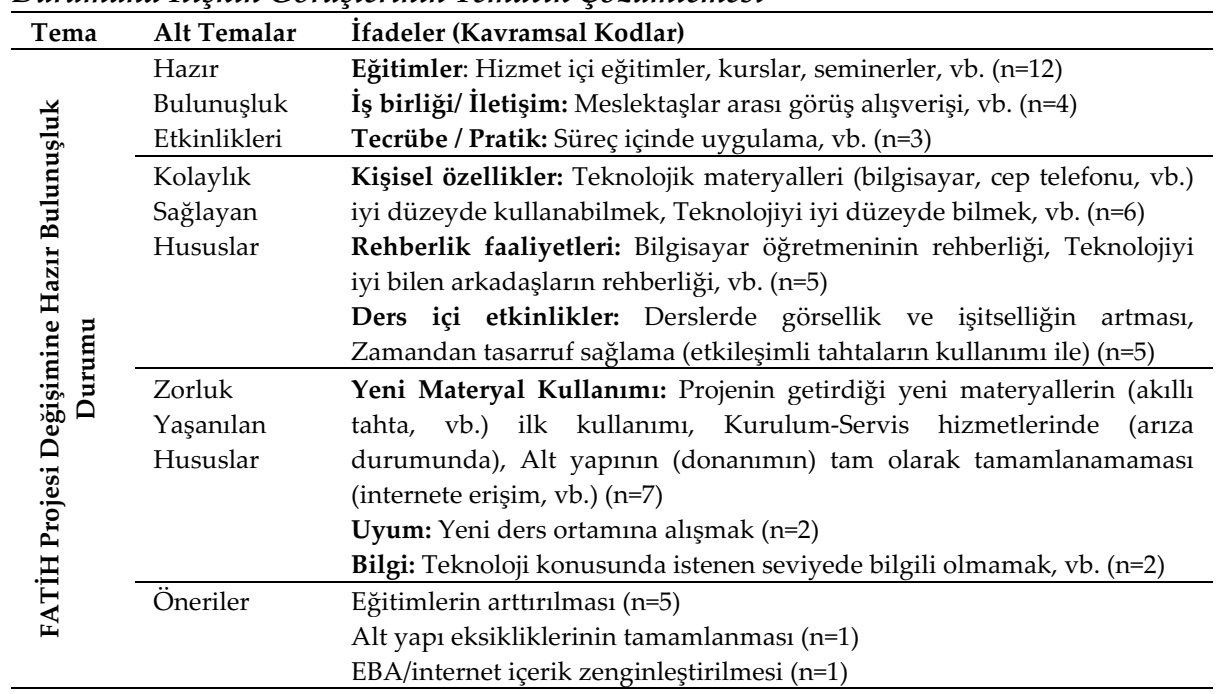

Tablo 4'te, FATİH Projesine hazır bulunuşluk sağlamada kolaylık sağlayan hususlar alt temasında; katılımcıların bir kısmı kişisel olarak teknoloji ile ilgili önceki ön bilgilerinin bu süreçte kendilerine kolaylık sağladığını belirtmiştir. Ayrıca, bilgisayar öğretmenlerinin ve teknolojiyi iyi düzeyde kullanan meslektaşların rehberliklerinin kendilerine kolaylık sağladığına, bazı katılımcılar ise elektronik tahtaların hız açısından kendilerine zamandan tasarruf yapmalarına kolaylık sağladığını ifade etmiştir. Bu konudaki örnek ifadeler; "Teknoloji ve bilgisayar ile ilgili bilgilerim bana kolaylık sağladı" (Ö:5), "Akıllı tahtalarda ders modüllerinin ve programın yüklü olması bize kolaylık sağlıyor, böylece tahtaları daha iyi kullanabiliyoruz" (Ö:10), "Bilgisayar öğretmenimiz bu süreçte bize yardımcı oluyor" (Y:2), şeklinde tespit edilmiştir.

Tablo 4'te, FATïH Projesine hazır bulunuşluk sağlamada zorluk yaşanılan hususlar alt temasında; Katılımcıların çoğu projenin getirdiği yeni materyallerin kullanımı sürecinde zorluk yaşadığı belirlenmiştir. Okul yöneticileri ise özellikle projenin teknik yönüne ilişkin 
materyallerin kurulumu ve hizmet servisine yönelik zorluklar yaşadıklarını belirtmiştir. Bu konudaki örnek ifadeler; "Akıllı tahtalarla ilk kez tanıştık. Illk başta açıp kapatmakta bile zorlandık. Kendim bol bol pratik yapıyorum" (Ö:3), "Mutlak suretle her yeniliğin bir zorluğu olacaktır. Bizde alt yapıyı oluştururken, materyallerin kurulumu sürecinde zorluk yaşadık." (Y:1), şeklinde tespit edilmiştir.

Tablo 4'te son olarak, FATİH Projesine hazır bulunuşluk durumuna yönelik öneriler alt temasında; görüş bildiren katılımcılar çoğunlukla ilgili projeye dönük eğitimlerin arttırılması yönünde öneri bildirmiştir. Ayrica alt yap1 eksikliklerinin tamamlanması ve EBA/internet içeriklerinin zenginleştirilmesine dönük öneriler dile getirilmiştir. $\mathrm{Bu}$ konudaki örnek ifadeler; "Tüm branşlara yönelik olarak daha zengin bir içerik oluşturulmalı. Ben Müzik öğretmeniyim branşıma ait dokümanların zenginleştirilmesini öneriyorum ve tahtaların internet bağlantısının sağlanması iyi olur" (Ö:6), "Alt yapr eksiklikleri tamamlanmalı" (Y:2), şeklinde tespit edilmiştir.

\section{Tartışma ve Sonuç}

Araştırma sonucunda katılımcıların okullarda başarılı değişimlerin gerçekleştirilmesini sağlayan temel başarı faktörlerine ilişkin; çalışanlara, kuruma ve gerçekleştirilmesi planlanan değişimin özelliğine yönelik faktörler belirttiği tespit edilmiştir. Değişim süreci ile ilgili alan literatürüne bakıldığında, değişimlerin başarıya ulaşması için pek çok faktörün öne sürüldüğü görülmektedir. Özdemir (2013); Erdoğan (2012); Fullan (2007); Kotter (1996) gibi pek çok araştırmacı değişimin uzun vadeli bir süreç olduğuna ve sürecin bireysel ve örgütsel yönünü belirtmekte; sürece katılan kişilerin değişime bakış açısının, destek ve inancının önemine değinerek, kurumsal olarak değişim süreci ile birlikte yeni görev ve rollerin ortaya çıkacağı, yeni grupların doğacağı, örgütsel iklimin bu süreçten olumlu ya da olumsuz etkilenebileceği, değişim için güven ortamının hakim olmasının önemine değinerek; ayrıca değişim ihtiyacının ve aciliyetinin hissedilmesinin ve taraflarca paylaşılmasının sürece olumlu katkısına dikkat çekerek, bu faktörlerin süreçlerin başarısına etki edebileceğini belirtmektir. Düren (2000, akt.Tuncer, 2013) başarılı değişimler ve yönetimi için üzerinde durulması gereken başlıca 
hususlarl; değişime yönelik ihtiyacın sezilmesi ve teşhis edilmesi, değişimle ilgili örgütün her düzeyi tarafından paylaşılacak ortak bir vizyon ve onunla uyumlu stratejilerin yaratılması, sürece etkin katılımı sağlamak için çalışanlar arası koalisyonun oluşturulması, değişimden en çok etkilenecek kişi ve mevkilere motor rollerin verilmesi, onların teşvik edilmesi, iletişim, ikna ve eğitim faaliyetlerine gereken önemin verilmesi, gibi konuları olarak sıralayarak, süreçte hem kişiye hem de örgüte yönelik etmenler belirtmiştir.

$\mathrm{Bu}$ araştırmanın sonucunda, değişime hazır bulunuşluk (hazır olma) durumunun önemine ilişkin katılımcların olumlu tutumu saptanmıştır. Böylece eğitimde başarılı değişimler gerçekleştirme sürecinde etkili olan faktörlerden birisi olarak 'değişime hazırbulunuşluk durumu' söylenebilir. Benzer şekilde, Bilgi Teknolojileri Liderlik Akademisi (The Information Technology Leadership Academy [ITLA], 2014)'nin yayınladığı 'Başarılı Değişimlerin Beş Ayă̆ı' adlı kılavuzda değişime hazır bulunuşluk bu temel unsurlardan birisi olarak belirtilmektedir, ayrıca hazır bulunuş başarılı değişimler için bir gösterge olarak nitelendirilmekte ve örgütün mevcut durumu ile geleceğe ilişkin durumunun bir ölçüsü olarak değerlendirilmektedir. Kondakçı, Zayim ve Çalışkan (2010) da çalışmalarının sonuç bölüümnde, değişime hazır olma durumu ile deneyim arasında pozitif ilişki saptamış ve değişime hazır olma durumu, değişim girişimlerinin başarıya ulaşması için önemli gerekliliklerden biridir, şeklinde ifade etmişlerdir. Buna ek olarak, Şahin (2018) çalışmasında öğretmenlere göre okulların fiziki alt yapısının örgütsel değişime hazır olduğunu ancak yöneticilerin, velilerin, öğretmenlerin ve okuldaki yardımcı personelin örgütsel değişsime yeterli düzeyde hazır olmadığı sonucuna ulaşmıştır ki bu sonuç okul çalışanlarının değişimlere uyum sağlamada sorunlar yaşayabilme olasılığını göstermektedir. Helvacı ve Kıcıroğlu (2010) ise ilköğretim okullarının değişime hazır bulunuşluklarını değerlendirme bağlamındaki çalışma bulgularında hem öğretmenlerin hem de okul yöneticilerinin değişime hazır bulunuşluğunu orta düzey saptanmıştır. Bu bulgu da süreçte hazır oluşu iyi düzeyde sağlamak için bu konuda pek çok çalışmanın yapılması gerektiğine işaret etmektedir. Tuncer (2013) de değişmeye alışmamış ve kendisini değişime hazırlamamış olan 
çalışanların değişimlere tepkilerinin ciddi boyutlara ulaşabileceği uyarısında bulunmuştur.

Katılımcıların FATïH Projesi değişimine yönelik hazır bulunuşluk durumları incelendiğinde, hazır bulunuşu sağlamak için katılımcıların tamamına yakınının projeye yönelik düzenlenen 'hizmet içi eğitimlere (seminerler)' katıldıkları saptanmış, ayrıca meslektaşlar arasında görüş alışverişinin sıklıkla yapıldığı; bilgisayar öğretmenlerinin bu süreçte okul çalışanlarını bilgilendirme ve rehberlik yönünden önemli görevler yürüttüğü belirlenmiştir. Benzer şekilde, Imants, Wubbels ve Vermunt (2013) öğrenen bir çevre geliştirmenin yenilikçi öğretmenlerin gelişmesi sürecindeki önemine vurgu yapmakta ve iş birliğinin (collaboration) önemini belirtmektedir ve ortak paylaşım, birlikte iş yapma, birlikte problem çözme, gibi etkinliklerin örgütlerde yenilikçi bir öğrenme ortamının sağlanmasına yardımcı olduğu belirtilmektedir.

Katılımcıların FATİH Projesi değişimine hazır bulunuşluğunu sağlama sürecinde, çalışanlara kolaylık sağlayan veya zorluk yaratan durumlar incelendiğinde; katılımcıların çoğunun kişisel olarak teknoloji ile ilgili ön bilgilerinin bu süreçte kendilerine kolaylık sağladığı, ayrıca bilgisayar öğretmenlerinin ve teknolojiyi iyi düzeyde kullanan meslektaş rehberliklerinin kendilerine kolaylık sağladığı belirlenmiştir. Katılımcıların çoğunun projenin getirdiği yeni materyallerin kullanımında zorluklar yaşadığı veya yaşamaya devam ettiği de belirlenmiştir, ders içi deneyim ile sürece daha iyi uyum sağladıkları belirlenmiştir. Helvacı (2010, s.49, Morrison, 1998'den esinlenerek) çalışmasında değişimi kolaylaştıran veya engelleyen faktörlerin olabildiğinden bahsetmiştir, değişimin başlangıç sürecinde değişimin açık ve iyi yapılandırılmış olmasının, gönüllülük, etkin katılım ve destek, kaynakların hazır olması, sürekli gelişim için katkıda bulunulması, gibi faktörleri değişimi kolaylaştırıcı faktörler olarak ifade etmiş; değişimin açık ve net olmamasını, desteğin olmamasını, kaynakların sınırlı olmasını, üst liderlerin engelleyici tavırları olması, sürekli gelişim yönünün bulunmaması, gibi faktörleri ise değişimi engelleyici faktörler olarak belirtmiştir. FATïH Projesi değişim örneği bağlamında Kurt, Kuzu, Dursun, Güllüpınar ve Gültekin (2013)'in hazırladıkları nitel çalışmada öğretmenlerin proje bileşenlerinden olan etkileşimli tahta ve tabletlerle ilgili teknik sorunlar yaşadıkları tespit edilmiştir ve 
öğretmenlerin FATİH Projesiyle birlikte teknolojinin artan kullanımı konusunda süreçte yer alan paydaşlar arasında dayanışmanın gerçekleştiği belirlenmiştir. Bu bulgu çalışmamızı destekler niteliktedir.

Çalışma sonucunda öneriler alt temasında katılımcıların değişimlere dair eğitimlere istekli olduğu belirlenmiştir. Benzer şekilde, Ulus (2009, s.67)'da öğretmenlerin hizmet içi eğitim almak istedikleri konuların en çok 'teknolojik yenilikler' ve 'eğitim öğretim teknikleri' konuları olduğu bulgusunu paylaşmıştır. Kıranlı ve Yıldırım (2014) öğretmenlerin hizmet içi eğitimlere sıklıkla güncel gelişmelere uyum sağlamak amacıyla katıldığını belirtmiştir. Bu bulgular çalışmamızı destekler niteliktedir.

Araştırmadan elde edilen bulgulara dayalı olarak; uygulayıcılara, araştırmacılara ve politika yapıcılara aşağıdaki öneriler sunulabilir:

- Bu çalışmada, değişimlerde başarı sağlayan faktörlerden başlıcası, okul çalışanları arasındaki ilişki (olumlu okul kültürü ve iş birliği) ve kurumun fiziki ortamının uygunluğu/hazır oluşu olarak karşımıza çlkmıştır. Bu sebeple, bu hususlar göz önünde tutularak okullarda değişimler başlatılırken öncelikle okul çalışanları arasında koordineli çalışma ortamlarının hazırlanması ve gerekli fiziki alt yapının hazır hale getirilmesi önerilmektedir.

- Bu çalışmada "FATİH Projesi" değişim örneğine yönelik okul çalışanlarının hazır bulunuşluk durumlarını sağlamak için yapılması gerekenlere yönelik; katılımcıların çoğunlukla eğitimlerin (seminer, kurs, vb.) arttırılması ve teşviki yönünde öneriler dile getirmiştir. Bu nedenle, öğretmenlerin bu değişim projesi sürecinde gelişimlerine katkı sağlayıcı hizmet içi eğitim ve kursların sayısının arttıılması, ayrıca bu eğitimlerin içeriklerinin uygulamaya dönük şekilde hazırlanmasına özen gösterilerek planlama yapılması önerilmektedir.

- $\mathrm{Bu}$ çalışmada nitel araştırma yöntemlerinden görüşme tekniği kullanılmıştır. Bu konuda araştırma yapmak isteyen araştırmacıların gözlem, odak görüşme tekniği, gibi farklı araştırma tekniklerini de kullanarak yeni çalışmalar gerçekleştirmesi önerilmektedir.

- Bu çalışmada "değişime hazır bulunuşluk" teması FATİH Projesi değişimine yönelik incelemeye alınmıştır, bu temanın okullarda başlatılan ya da yeni başlatılacak daha farklı değişim örneklerinin de ele alınarak incelenmesi önerilmektedir. 


\section{EXTENDED ABSTRACT}

\section{An Investigation of School Administrators and Teachers' Readiness for Changes (A Case Study in Gaziantep) \\ * \\ Aykar Tekin Bozkurt \\ Gaziantep University}

Change and innovation are the most widely used terms in today's world. Change is a process involving certain stages (Erdoğan, 2012, p.17). Lewin (1947), who conducted significant studies on the process of change, addressed change through a three-stage model; unfreezing, moving and refreezing. In this model, unfreezing refers to the organization's preparation for change, moving refers to the change of thoughts, feelings and behaviors among employees so that the organizational change can take place, and the refreezing stage refers to the supporting of new behavioral patterns to sustain change within the organization. The attitude of the people working in organizations towards change is a matter of importance. Failure to thoroughly understand the employees' attitude towards change and neglecting to transform employees' attitudes during the process of change from usually negative (anxiety, stress, insecurity, indecision, etc.) into positive attitudes may cause successive disadvantages during the process of change that trigger one other. Therefore, the employees' readiness for change is a matter of importance for the success in a process of change.

This study was conducted in order to gain an understanding of school employees' (school managers and teachers) readiness for change in relation to the example set by "FATİH PROJECT: A Project of Action to Increase Opportunities and Improve Technology" that has been recently implemented in schools throughout Turkey. This study addressed the "FATIH PROJECT", one of the newest initiatives of change that has been implemented in schools with respect to the "readiness for change at schools". The main question of the study was: "What is the level of readiness among school employees during the process of change and what are the main considerations/factors affecting this?" Within this 
context, answers were sought for the sub-questions "What are the main considerations/factors that are considered to be important by the school employees (managers and teachers) for them to successfully undergo change?"; "What school employees' (managers and teachers) opinions as to the importance of ensuring readiness for change, when initiating any change?", and "What are the opinions of school employees when it comes to readiness for the 'FATIH PROJECT', which is a new change model in schools?".

\section{Methodology}

The study was conducted using the case study pattern, which is one of the qualitative study patterns. The data was collected through the semistructured interview technique, which is one of the qualitative study techniques. The data was obtained through the participation of school employees working at secondary education level in state schools in the central districts of Gaziantep Province during the 2014-2015 school year. The schools where the FATIH project was implemented were determined using the maximum variation sampling method, and a workgroup was constituted by the school employees working at those schools (teachers $n=10$, school managers $n=4$, total $n=14$ ). There was a total of 14 participants in the workgroup working in the central districts of Gaziantep Province. The content analysis method was used for the analysis of the data. During the content analysis process, frequency analysis and categorical analysis were preferred. The stages followed during the content analysis process of the study were: documenting the data in writing, creating an interview coding key, coding the interview data onto the coding key, comparing the coding and reliability study, and interpreting the results (Miles and Huberman, 1994; Y1ldirım and Şimşek, 2005, Bilgin, 2006, Saldana, 2009).

\section{Discussion and Conclusion}

According to the study results, a majority of the participants made statements about the employees, the institution, and the nature of change with regards to the main factors that are effective in realizing successful 
change. It was determined that the participants put weight on the relationship and collaboration between employees. It was observed that the school employees gave positive answers regarding the importance of the school employees' readiness for change, and indicated reasons related to the employees (improving self-confidence, communication, etc.) and the process (efficiency, control, etc.) as to why it was important. Furthermore, it was stated that the participants received training including in-service training, courses, and seminars, and frequently resorted to exchange of opinion between peers to ensure that they are ready for the FATIH Project. Some of the participants stated that their own preliminary knowledge of technology helped them during this change process. The participants emphasized that the guidance of computer teachers or their colleagues who were competent in technology facilitated their job, and they also indicated that they adapted to the process better by gaining experience during the activities conducted during the courses. These considerations were determined to be the main factors facilitating the process. In their study, Imants, Wubbels, and Vermunt (2013) emphasize the importance of creating a learning environment in raising innovative teachers, indicate the importance of collaboration, and state that activities such as sharing, working jointly, and solving problems together help create an innovative learning environment. In their studies, Kondakçı, Zayim and Çalışkan (2010:161) also detected a positive correlation between readiness for change and experience, and readiness for change is one of the vital requirements for the success of the initiatives of change. It was determined that most of the participant teachers experienced difficulties in using the new materials developed within the scope of the project during the initial stage.

Finally, it was revealed that the participants frequently made suggestions that the training should be improved and the deficiencies in the infrastructure be eliminated. Based on these results, it was recommended that the in-service training and courses the school employees receive to improve themselves during the process of transformation to the FATIH Project be increased, and care be taken to prepare the content of the training so that willing teachers can participate in an applied way. 


\section{Kaynakça / References}

Akan, D. (2007). Değişim sürecinde ilköğretim okullarının etkili okul özelliklerine sahip olma düzeyleri (Erzurum ili örneği). Doktora Tezi. Atatürk Üniversitesi, Sosyal Bilimler Enstitüsü, Erzurum.

Armenakis, A. A., Harris, S. G. and Mossholder, K. W. (1993). Creating readiness for organizational change. Human Relations, 46, 681-703.

Bilgin, N. (2006). Sosyal bilimlerde içerik analizi teknikler ve örnek çalışmalar. Ankara:Siyasal Kitabevi.

Camba, P. and Krotov, V. (2015). Critical success factors in the curriculum alignment process: The case of the college of business at Abu Dhabi University. Journal of Education For Business, 90, 451-457.

Çağlar, İ. (2015). Bireysel, örgütsel ve toplumsal düzeyde değişim ve değişim yönetimi. Ankara: Nobel Akademik Yayıncllik.

Demirtaş, H. (2012). İlköğretim okullarının değişime açıklığı. İlköğretim Online, 11(1), 18-34.

Erdoğan, İ. (2012). Eğitimde değişim yönetimi (3.Baskı). Ankara: Pegem Yayıncilik.

FATIH Projesi. Fırsatları Artırma ve Teknolojiyi İyileştirme Hareketi. Erişim adresi: http://fatihprojesi.meb.gov.tr , 01.10.2015 tarihinde erişildi.

Fullan, M. (2007). The new meaning of educational change (4th edition). New York: Teachers College Press.

Gürses, G. (2010). Ilköğretim okullarında meydana gelen değişimlere karşı direnişler ve nedenleri (İzmir ili örneği). Yüksek Lisans Tezi. Uşak Üniversitesi, Sosyal Bilimler Enstitüsü, Uşak.

Helvac1, M.A. (2010). Eğitim örgütlerinde değişim yönetimi. Ankara: Nobel Yayınları.

Helvacı, M. A.,ve Kıcıroğlu, B. (2010). İlköğretim okullarının değişime hazır bulunuşluk düzeyleri (Uşak ili örneği). Akademik Bakiş Dergisi, 21, 130.

Imants, J., Wubbels T. and Vermunt, J. D. (2013). Teachers' enactments of workplace conditions and their beliefs and attitudes toward reform. Vocations and Learning, 6, 323-346.

Karataş, Z. (2015). Sosyal bilimlerde nitel araştırma yöntemleri. Manevi Temelli Sosyal Hizmet Araştırmaları Dergisi, 1(1), 62-80.

Kaya, Z. (2014). Eğitimin psikolojik temelleri. (4.Bölüm). Demirel, Ö. ve Kaya, Z. (Ed.) Eğitim Bilimine Giriş (s.97-127) içinde. Ankara: Pegem Akademi Yayıncilı. 
Kıranlı, S. ve Yıldırım, Y. (2014). Okul yöneticileri ile öğretmenlerin hizmet içi eğitim etkinliklerine ilişkin görüşlerinin karşılaştırılması. Dicle Üniversitesi Ziya Gökalp Ĕ̆itim Fakültesi Dergisi, 23, 219-251.

Kondakçı, Y., Zayim, M. ve Çalışkan, Ö. (2010). Okul yöneticilerinin değişime hazır olma tutumlarının okulun öğretim düzeyi, yöneticilerin deneyimi ve okul büyüklüğü bağlaminda incelenmesi. İnönü Üniversitesi Ĕ̆itim Fakültesi Dergisi, 11(2), 155-175.

Kotter, J. P. (1996). Leading change. Boston: Harvard Business School Press.

Kurt, A. A., Kuzu, A., Dursun,Ö.Ö., Güllüpınar, F., ve Gültekin, M. (2013). FATIH Projesinin pilot uygulama sürecinin değerlendirilmesi: Öğretmen görüşleri. Journal of Instructional Technologies \& Teacher Education, 1(2), 1-23.

Miles, M. B., and Huberman, A. M. (1994). Qualitative data analysis: A Sourcebook of new methods, Thousand Oaks, CA:Sage Publications.

Nespor, J. (2000). Anonymity and place in qualitative inquiry. Qualitative inquiry, 6(4), 546-569.

Özdemir, S. (2013). Eğitimde örgütsel yenileşme (7.Baskı). Ankara:Pegem Akademi Yayınları.

Saban, A. ve Ersoy, A. (2017). Ĕ̆gitimde nitel araştırma desenleri. Ankara:Anı Yayıncilik.

Şahin, M. (2018). Öğretmenlerin eğitim örgütlerinde yaşanan değişim sürecine ilişkin görüşleri. Türkiye Sosyal Araştirmalar Dergisi, 22(3), 875-895.

The Information Technology Leadership Academy, Organizational Change Management. Readiness Guide, ITLA, (2014). Erişim adresi: http://www.cio.ca.gov/opd/pdf/itla/21/OCM-FISCal-ReadinessGuide.pdf 01.11.2015 tarihinde erişildi.

Tuncer, P. (2013). Değişim yönetimi sürecinde değişime direnme. Ondokuz Mayıs Üniversitesi Ĕ̆itim Fakültesi Dergisi, 32(1), 373-406.

Yıldırım, A. ve Şimşek, H. (2005). Sosyal bilimlerde nitel araştırma yöntemleri. Ankara: Seçkin Kitapevi.

Ulus, O. (2009). Hizmet içi eğitim faaliyetlerinin öğretmen görüşlerine göre değerlendirilmesi (Konya ili uygulaması). Yüksek Lisans Tezi. Gazi Üniversitesi, Eğitim Bilimleri Enstitüsü, Ankara.

Willower, D., J. (1963). Barriers to change in educational organizations theory into practice. Changing the School, 2(5), 257-263. 
Woodall, J. (1996). Managing culture change: Can it ever be ethical?. Personnel Review, 25(6), 26-40.

\section{Kaynakça Bilgisi / Citation Information}

Bozkurt, A. T. (2021). Okul yönetici ve öğretmenlerinin değişime hazır bulunuşluk durumlarının incelenmesi (Gaziantep ili örneği). OPUS-Uluslararası Toplum Araştırmaları Dergisi, 18(Yönetim ve Organizasyon Özel Sayıs1), 1285-1307. DOI: 10.26466/opus.844249. 